\title{
PENINGKATAN NILAI TAMBAH MELALUI PENGOLAHAN PRODUK HORTIKULTURA
}

\author{
Sri Ayu Andayani*, Dinar, Ida Marina, Kosasih Sumantri, Jaka Sulaksana, Sri Umyati, \\ Umar Dani \\ Fakultas Pertanian Universitas Majalengka \\ *Email: sriayuandayani@unma.ac.id
}

\begin{abstract}
Horticultural product processing training in increasing added value for farmers or business actors in this case for mothers and farmer groups in Argalingga Village, Argapura District as well as students is the theme of community service. This activity is in collaboration with the Representative Office of Bank Indonesia Cirebon. The method applied in this service activity uses a participatory method, namely before the implementation of practical activities, the participants are directed and given an understanding of the theory first. As a result of this activity, the participants actively participate through discussion and practice so that the participatory method can be implemented. Improved knowledge, attitudes, and skills can be obtained from this training through direct discussion and question and answer so that indicators of success can be measured. The hope of this activity is that participants can be motivated to carry out continuous processing of horticultural products so that an increase in added value can be achieved.
\end{abstract}

Keywords: added value; product; processing; horticulture; participatory

\begin{abstract}
Abstrak
Pelatihan pengolahan produk hortikultura dalam peningkatan nilai tambah bagi petani atau pelaku usaha dalam hal ini bagi ibu-ibu dan kelompok tani yang berada di Desa Argalingga Kecamatan Argapura juga mahasiswa merupakan tema dari pengabdian kepada masyarakat. Kegiatan ini Kerjasama dengan Kantor Perwakilan Bank Indonesia Cirebon. Metode yang diterapkan dalam kegiatan pengabdian ini menggunakan metode partisipatif yaitu sebelum pelaksanaan kegiatan praktek, para peserta diarahkan dan diberi pemahaman teori terlebih dahulu. Hasil dari kegiatan ini, para peserta aktif berperan melalui diskusi dan praktek sehingga metode partisipatif dapat terlaksana. Peningkatan pengetahuan, sikap, dan keterampilan dapat diperoleh dari pelatihan ini dengan diskusi dan tanya jawab secara langsung sehingga indicator keberhasilan dapat terukur. Harapan dari kegiatan ini peserta dapat termotivasi melaksanakan pengolahan produk hortikultura dengan kontinyu sehingga peningkatan nilai tambah dapat dicapai.
\end{abstract}

Kata Kunci: nilai tambah; produk; pengolahan; hortikultura; partisipatif

\begin{tabular}{l|l|l} 
Submitted: $2021-08-30$ & Revised: $2021-10-08$ & Accepted: 2021-10-26
\end{tabular}

\section{Pendahuluan}

Pertanian merupakan salah satu sector ekonomi utama di Provinsi Jawa Barat, termasuk hortikultura. Hortikultura merupakan salah satu komoditi pertanian yang berpotensi dan berpeluang dikembangkan menajdi produk unggulan (Pitaloka, 2017). Petani ataupun masyarakat banyak yang melaksanakan usahatani komoditas hortikultura dan dijual langsung setelah panen tanpa adanya pengolahan lebih lanjut sehingga masyarakat kehilangan potensi dalam mendapatkan nilai tambah dari produk olahan tersebut (Simatupang W, 2018).

Dengan semakin banyaknya kebutuhan masyarakat, maka diperlukan berbagai upaya ke arah peningkatan produksi olahan ( Amelia Julfi, et al, 2019). Cabai merah salah satu komoditas hortikultura yang mempunyai nilai manfaat bagi kebutuhan masyarakat sehingga semakin tinggi permintaannya (Yudohusodo, 1999), namun demikian karakteristik produk hortikultura yang tidak tahan lama, maka perlu adanmya pengolahan. Hal inilah yang mendasari dipilihnya pelatihan pengolahan produk hortikultura dalam kegiatan pengabdian kepada masyarakat, juga salah satu Kerjasama Fakultas Pertanian Universitas Majalengka dengan Kantor Perwakilan Bank Indonesia Cirebon. Kegiatan dilaksanakan di Desa Argalingga Kecamatan Argapura pada bulan Juni Tahun 2021 dengan sasaran peserta ibu-ibu dan para mahasiswa. Hal ini didasari dengan perlunya 
pemberdayaan ibu-ibu dengan potensi yang dimiliki dalam peningkatan nilai tambah produk dan pendapatan serta pemenuhan kebutuhan akan produk olahan hortikultura. Tujuan dari pelaksanaan kegiatan ini untuk mengenalkan teknik pengolahan produk hortikultura khususnya cabai merah, peningkatan peran ibu-ibu dalam penyedia produk olahan serta peningkatan sikap, keterampilan dalam pengolahan produk hortikultura.

\section{Metode}

Kegiatan ini telah dilaksanakan pada ibu-ibu di Desa Argalingga sebanyak 15 orang dan mahasiswa fakultas pertanian Unievrsitas Majalengka dengan pendamping dari kelompok tani Mekarmulya Argalingga serta dari Kantor Perwakilan Bank Indonesia Cirebon. Alat dan Bahan yang diperlukan dalam kegiatan ini meliputi: cabai merah, alat - alat memasak, kompor dan lain sebagianya.

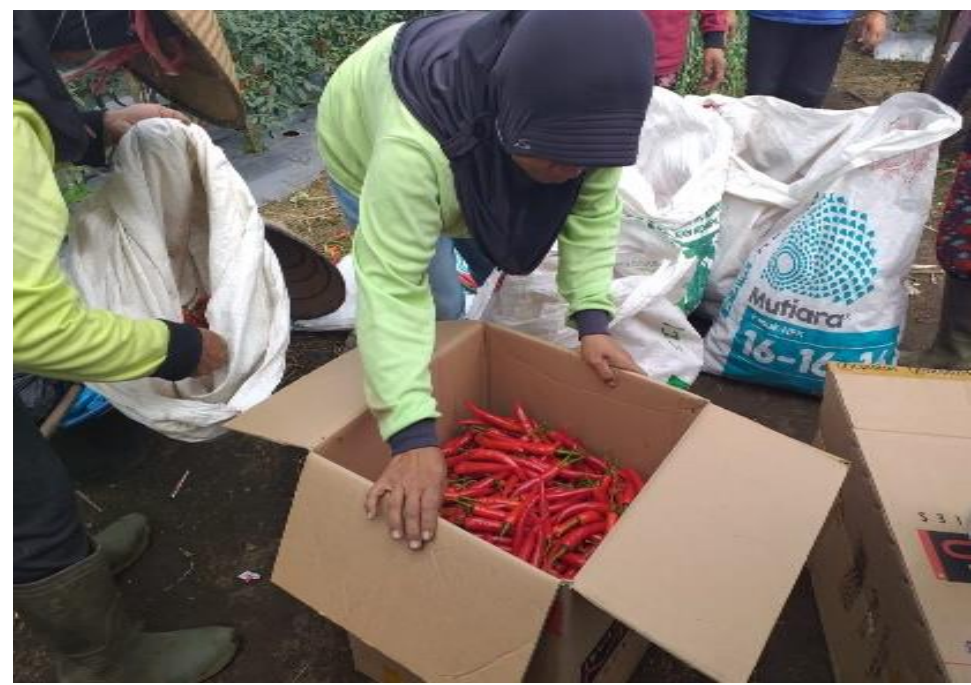

Gambar 1. Persiapan Cabai Merah

Pelaksanaan kegiatan dengan menggunakan metode partisipatif atau metode training. Kegiatan diawali dengan pemberian materi teknik pengolahan produk hortikultura oleh dosendosen dan dari Kantor Perwakilan Bank Indonesia Cirebon. Setelah para peserta mendapatkan materi dilanjutkan dengan praktek langsung secara mandiri dengan bimbingan fasilitator.
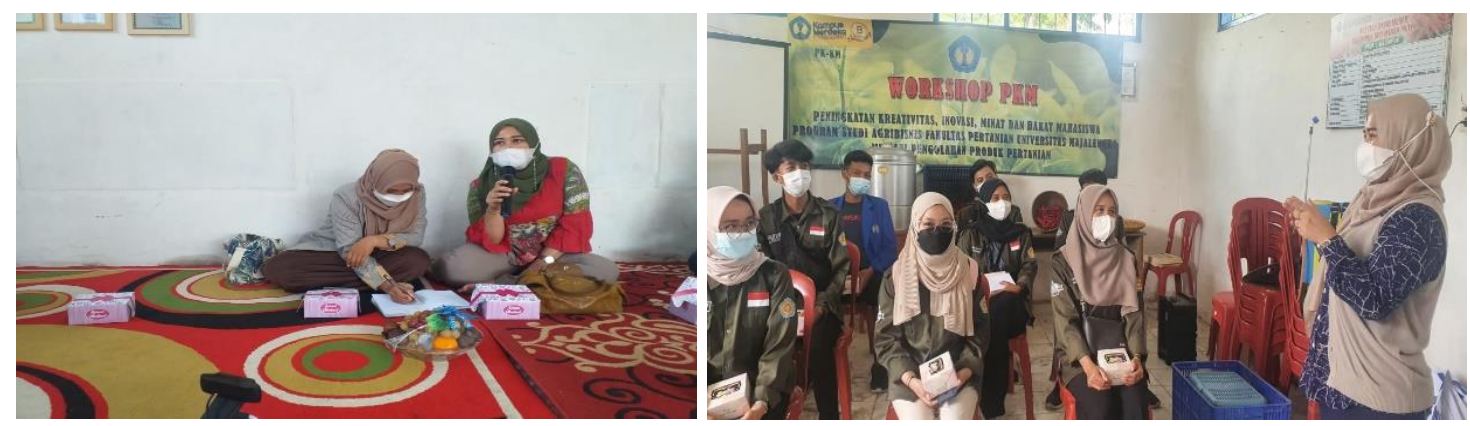

Gambar 2. Pemberian materi

Beberapa tahapan dalam kegiatan ini meliputi: (1) pemberian materi terkait produk hortikultura dan teknik pengolahan, (2) demonstrasi langkah-langkah pengolahan dan praktek langsung, (4) Evaluasi 


\section{Hasil dan Pembahasan}

Kegiatan pengolahan merupakan kegiatan strategis dalam meningkatkan nilai dalam mata rantai produksi dan menciptakan keunggulan kompetitif (Purwanto $H, 2009$ ). Pengolahan berfungsi pula selain meningkatkan nilai tambah, juga menghasilkan produk yang dapat dipasarkan atau dikonsumsi, meningkatkan daya saing serta meningkatkan pendapatan dan keuntungan petani.

Dosen yang tergabung dalam kegiatan pelatihan ini, aktif memberikan materi juga mendampingi para peserta. Penyampaian materi dilakukan sekitar 1 jam disertai diskusi aktif.

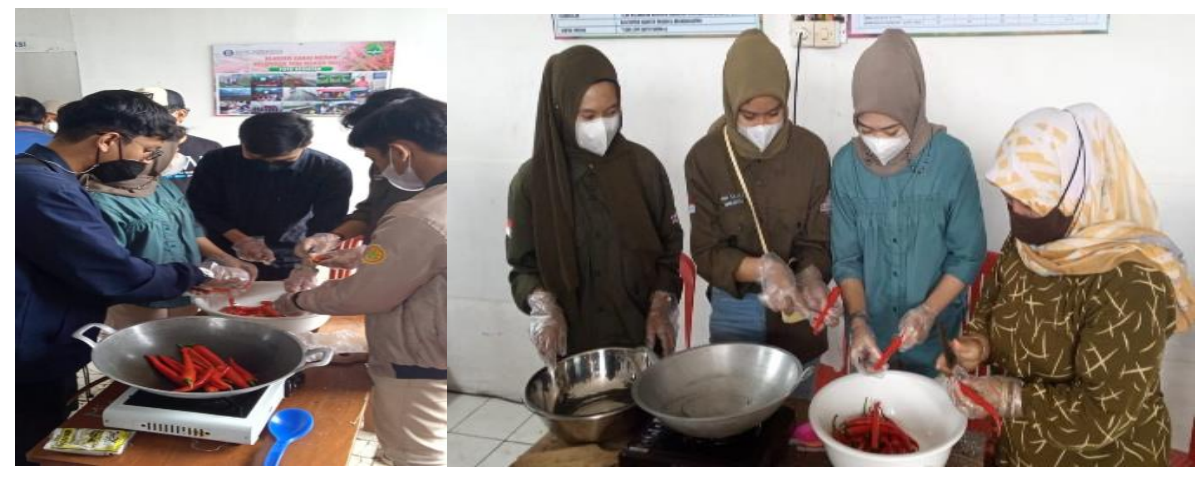

Gambar 3. Persiapan alat perlengkapan pengolahan

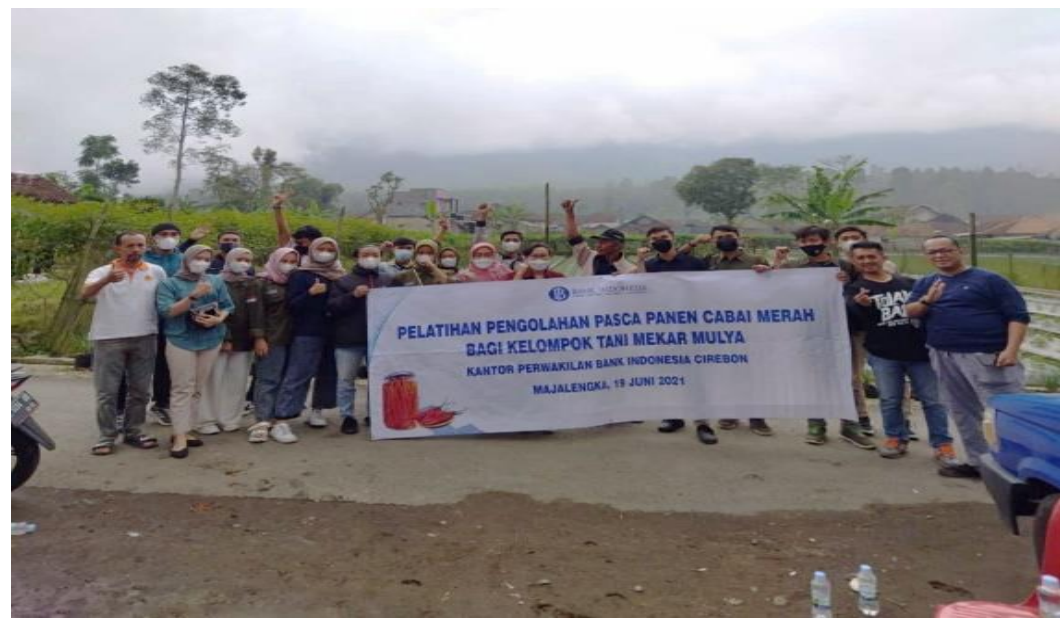

Gambar 4. Foto bersama dengan steakholder yang terlibat

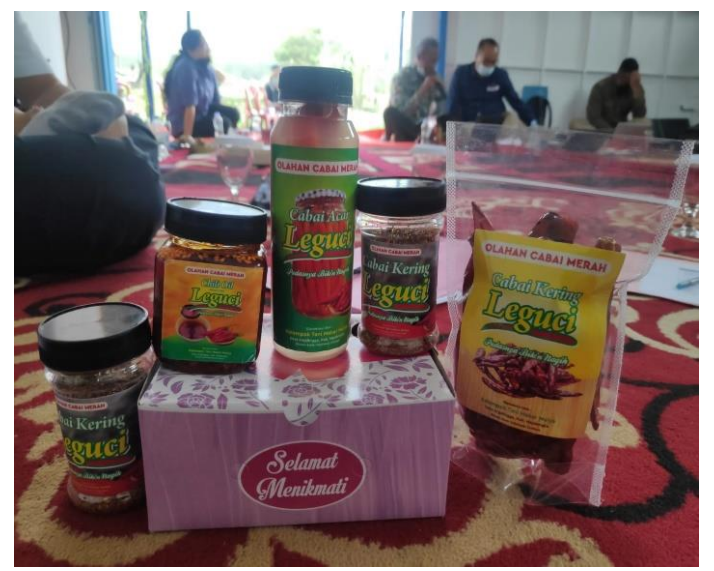

Gambar 5. Hasil olahan produk siap dipasarkan 
Penyampaian materi telah selesai, maka lanjut pada kegiatan praktek yang langsung dikuti para peserta. Bahan baku yaitu cabai merah dicuci bersih terlebih dahulu kemudian masukkan pada wadah bersih seperti terlihat pada Gambar 3. Melihat hasil pada kegiatan pengabdian masyarakat khususnya pelatihan pengolahan produk hortikulktura dalam hal ini cabai merah dapat dikatakan sesuai dengan harapan, respon para peserta antusias dan aktif berpartisipasi dengan para dosen dan pendamping baik dari Perguruan Tinggi maupun dengan dari Bank Indonesia Cirebon. Keberhasilan dari kegiatan ini dapat dilihat pada indicator keberhasilan Tabel 1.

Tabel 1. Indikator Keberhasilan Kegiatan Pelatihan Pengolahan Produk Hortikultura

\begin{tabular}{llcc}
\hline No & \multicolumn{1}{c}{ Indikator } & Sebelum Kegiatan (\%) & Setelah Kegiatan (\%) \\
\hline 1 & Terlaksananya program pelatihan & 0 & 100 \\
2 & Tingkat aktif partisipatif peserta & 0 & 100 \\
3 & $\begin{array}{l}\text { peningkatan sikap, pengetahuan, } \\
\text { keterampilan peserta }\end{array}$ & 0 & 85 \\
4 & Nilai tambah & 0 & 55 \\
\hline
\end{tabular}

Kegiatan pelatihan pengolahan produk hortikultura dapat dikatakan sesuai harapan dengan dasar bahwa pengetahuan dari pengolahan telah didapatkan para peserta, namun belum dapat dikatakan mendapatkan nilai tambah sehingga belum mencapai angka 100, dikarenakan belum terlihat apakah mereka dapat terus melaksanakan kegiatan pengolahan produk secara kontinyu.

\section{Kesimpulan}

Berdasarkan hasil dan pembahasan dapat diberikan kesimpulan bahwa kegiatan pengabdian kepada masyarakat yang dilakukan Fakultas Pertanian Universitas Majalengka bekerjasama dengan Kantor Perwakilan Bank Indonesia Cirebon, mengadakan pelatihan pengolahan produk hortikultura dengan tahapan mulai penyampaian materi, melakukan demonstrasi praktek langsung hingga kegiatan monitoring dan evaluasi. Kegiatan ini dilaksanakan dengan lancar dan berhasil sesuai dengan indicator pengukuran keberhasilan, melalui peningkatan pengetahun, sikap, dan keterampilan. Kegiatan ini ke depan harus dilaksanakan secara kontinyu sebagai peningkatan nilai tambah dari produk hortikultura.

\section{Daftar Pustaka}

Amelia Julfi Restu, Ira Mulyawati, Lisa Ratnasari. (2019). Diversifikasi Produk Olahan Pangan Hasil Aplikasi Vertikultur Tanaman Sayuran di Kelurahan Tengah, Kramat Jati, Jakarta Timur (Diversification of Food From Verticulture Applications of Vegetable Plants in Tengah Village, Kramat Jati, East Jakarta). Agrokreatif, Jurnal Ilmiah Pengabdian Kepada Masyarakat, 5(3), 216-225.

Dyah Pitaloka. (2017). Hortikultura; Potensi, Pengembangan dan Tantangan. G-Tech Jurnal Teknologi Terapan. FTIKA Unira Malang, 1 (1).

Helmy Purwanto. (2009). Teknologi Pengolahan Hasil Pertanian. MEDIAGRO Jurnal Ilmu-ilmu Pertanian. 5(1), 15-19.

Simatupang Wita. (2018). Potensi Pengembangan Produk Olahan Pertanian untuk Mendukung Perkembangan Pariwisata. Jurnal Muara, 2 (2).

Siswono Yudohusodo. (1999). Upaya Pemberdayaan Petani sebagai Faktor Utama Program pembangunan Nasional. Gerakan Terpadu Peduli Pertanian,UNDIP Semarang. 